\title{
Dietary patterns and chronic kidney disease risk: a systematic review and updated meta-analysis of observational studies
}

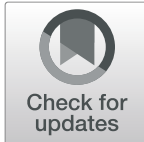

\author{
Ling-Qiong He${ }^{1}$, Xu-Hong Wu${ }^{2}$, Yi-Qian Huang ${ }^{3}$, Xiao-Yan Zhang ${ }^{4}$ and Long Shu ${ }^{4}$
}

\begin{abstract}
Background: A number of studies have reported the association between dietary patterns and the risk of chronic kidney disease (CKD), however a consistent perspective hasn't been established to date. Herein, we conducted this systematic review and meta-analysis of observational studies to assess the association between dietary patterns and CKD.

Methods: MEDLINE, EBSCO and references from eligible studies were searched for relevant articles published up to 9 May 2020 that examined the association of common dietary patterns and CKD. The heterogeneity among studies was assessed by Cochran's $\mathrm{Q}$ test and $\mathrm{I}^{2}$ methods.

Results: Seventeen eligible studies, involving 149,958 participants, were included in our systematic review and metaanalysis. The highest compared with the lowest category of healthy dietary pattern was significantly associated with a lower risk of $\mathrm{CKD}(\mathrm{OR}=0.69 ; \mathrm{Cl}: 0.57,0.84 ; P=0.0001)$. A higher risk of $\mathrm{CKD}$ was shown for the highest compared with the lowest categories of Western-type dietary pattern $(\mathrm{OR}=1.86 ; \mathrm{Cl}: 1.21,2.86 ; P=0.005)$. There were evidence of a lower risk of $\mathrm{CKD}$ in the highest compared with the lowest categories of light-moderate drinking pattern ( $\mathrm{OR}=0.76 ; \mathrm{Cl}: 0.71,0.81 ; P<$ $0.0001)$ and heavy drinking pattern (OR=0.67; $\mathrm{Cl}: 0.56,0.80 ; P<0.0001)$.

Conclusions: The results of this systematic review and meta-analysis show that a healthy dietary pattern and alcohol drinking were associated with lower risk of CKD, whereas a Western-type dietary pattern was associated with higher risk of CKD.
\end{abstract}

Keywords: Dietary patterns, Chronic kidney disease, Systematic review, Meta-analysis

\section{Introduction}

Chronic kidney disease (CKD) affects between 11 and $13 \%$ of adults worldwide and is recognized as a major global health concern [1]. In the United States, CKD is a common noncommunicable chronic disease, with an estimated 26 million adults in 2007 [2]. In Brazil, the prevalence of CKD is approximately $9 \%$, not including patients on dialysis [3]. In China, Zhang et al. reported that the overall prevalence of CKD surpassed 119.5 million

\footnotetext{
* Correspondence: shulong19880920@126.com

${ }^{4}$ Department of Nutrition, Zhejiang Hospital, Xihu district, Hangzhou 310013 Zhejiang, People's Republic of China

Full list of author information is available at the end of the article
}

(approximately $10.8 \%$ of the general population) in a nationally representative sample of Chinese adults [4]. Multiple risk factors for CKD, such as cardiovascular diseases, obesity, diabetes, smoking, and use of nephrotoxic medications have been well established [5]. In addition, dietary factors have also been acknowledged as the important risk factors for CKD [6].

In the past, some epidemiological studies particularly focused on dietary interventions as an important tool to prevent or slow down the adverse prognosis of CKD [7] and had well established the role of individual nutrients and foods and/or food groups on the risk of CKD $[8,9]$. However, in reality, individuals do not eat nutrients or

(c) The Author(s). 2021 Open Access This article is licensed under a Creative Commons Attribution 4.0 International License, which permits use, sharing, adaptation, distribution and reproduction in any medium or format, as long as you give appropriate credit to the original author(s) and the source, provide a link to the Creative Commons licence, and indicate if changes were made. The images or other third party material in this article are included in the article's Creative Commons licence, unless indicated otherwise in a credit line to the material. If material is not included in the article's Creative Commons licence and your intended use is not permitted by statutory regulation or exceeds the permitted use, you will need to obtain permission directly from the copyright holder. To view a copy of this licence, visit http://creativecommons.org/licenses/by/4.0/ The Creative Commons Public Domain Dedication waiver (http://creativecommons.org/publicdomain/zero/1.0/) applies to the data made available in this article, unless otherwise stated in a credit line to the data. 
foods in isolation, but consume meals containing combinations of many foods and nutrients that possibly interact with each other [10]. Consequently, dietary pattern analysis is now widely accepted in the realm of nutritional epidemiology as a more recognizable approach for assessing the relationship between diet and diseases, because it takes into account the complexity of whole-diet and potentially facilitates nutritional recommendations [11].

Up to now, there have been considerable attentions in medical research on the relationship between dietary patterns and the risk of CKD [12-19]. However, these studies have yielded inconclusive results. Therefore, to clarify the potential associations between dietary patterns and risk of CKD, we performed an updated metaanalysis to synthesize the results of studies published up to 9 May 2020.

\section{Methods}

\section{Literature search strategy}

An electronic literature search was conducted throughout MEDLINE (US National Library of Medicine, Bethesda, MD) and EBSCO (Elton B. Stephens Company) for identifying human studies written in the English and Chinese languages published up to 9 May 2020, that included the following keywords or index terms: "nutrition" OR "diet" OR "dietary pattern" OR "eating pattern" OR "food pattern" OR "alcohol drinking" OR "alcohol consumption" AND "chronic kidney disease" OR "kidney disease" OR "End-Stage Renal Disease" OR "ESKD" OR "CKD". In addition, we also manually searched the reference lists of the retrieved (including meta-analyses and brief reported) and gray literature for further eligible articles.

\section{Studies included criteria}

Two independent authors (Shu L and He LQ) read the titles and abstracts of the articles retrieved in the initial search to identify studies that reported the relationship between diet and CKD. Any disagreements between two independent reviewers were discussed and resolved by consensus or by a third independent reviewer (Huang YQ) if necessary. All authors agreed on the relevant articles, then the full-text articles were reviewed against inclusion and exclusion criteria for the present systematic review and meta-analysis.

To be eligible, studies had to fulfill the following criteria: (1) The study was an observational study; (2) reported the association between dietary and/or food patterns and CKD risk; (3) Factor analysis, reduced-rank regression and/or principal component analysis were used to identify dietary and/or food patterns; (4) Odds ratios (OR), hazard ratios (HR) or relative risks (RR) and percentage of CKD (or sufficient information to calculate them) had been listed;(5) CKD diagnoses were confirmed by clinical interviews, or self-report on a previous physician-made diagnosis of CKD.

Dietary patterns are defined as the intake of foods that reflect habitual dietary intake. To minimize error, the two independent authors ensured that the selected food or dietary patterns were similar with regard to factor loadings of foods, which are consumed within those dietary patterns. For instance, the first pattern, named as a prudent/healthy pattern tended to have high loadings of foods, such as vegetables, fruits, whole grain, fish, olive oil, soy and antioxidants(e.g. Vitamin C and E, flavonoids, and carotenoids), and low fat dairy; The second pattern, named as a western-style pattern tended to have high factor loadings for foods, such as refined grains, red and/or processed meat, sweets, desserts, butter, fast food and soft drink; The third pattern, named as a drinker pattern tended to have high loadings of beers, wines, and white spirits.

\section{Definition of "high intake"}

Dietary and/or food patterns were derived by using factor analysis and/or principal component analysis. Factor scores for each pattern were categorized into quintiles, quartiles, or tertiles (the lowest category and the highest category represent lowest and highest adherence to a specific dietary pattern, respectively.).The different forms of alcohol consumption were converted into grams of ethanol per day. Alcohol consumption of $>50 \mathrm{~g} / \mathrm{d}$ (4 drinks) for men or $>25 \mathrm{~g} / \mathrm{d}$ ( 2 drinks) for women was defined as a high consumption of alcohol or heavy drinking [20].

\section{Data extraction}

Two independent reviewers extracted the following information from all eligible studies: first author, publication year, country, study design, sample size, number of CKD, dietary assessment method, naming dietary patterns and the variables that were adjusted for in our analysis.

\section{Assessment of heterogeneity}

The Cochran's Q statistic and $I^{2}$ statistic were used to assess heterogeneity. A $P$ value of Q-test $>0.10$ or $I^{2}<$ $50 \%$ indicated an absence of heterogeneity between studies, and a fixed-effects model (Mantel-Haenszel method) was used to calculated the pooled ORs. If a $P$ value of Q-test $\leq 0.10$ or $I^{2} \geq 50 \%$ indicated a high degree of heterogeneity among studies, then a random-effects model (DerSimonnian and Laird method) was used [21].

\section{Quality assessment}

The same two reviewers used the Newcastle-Ottawa Quality Assessment scale [22] to assess the methodological 
quality of the included studies in the present meta-analysis. This scale consists of three main domains (selection of participants, comparability of participants, and assessment of outcome/ exposure) and eight questions in total. These questions were assessed and each satisfactory answer received 1 point (may receive 2 points in comparability categories), resulting in a maximum score of nine. Only these studies which the majority of the questions were deemed satisfactory(e.g. with a score of 6 or higher) were considered to be of high methodological quality [23].

\section{Data analysis}

The original studies reported the results of dietary pattern in terms of tertiles, quartiles and quintiles of dietary factor scores and the risk of CKD. We applied this systematic review and meta-analysis to assess the risk of CKD in the highest versus the lowest categories of healthy, Western-style and drinker dietary patterns. If original studies reported risk ratios (RR) or hazard ratios (HR) instead of OR, it was treated the same as OR when the reported prevalence of CKD was less than $20 \%$. Multivariable adjusted OR, HR and RR with 95\% CIs from individual studies were weighted and combined to produce an overall OR. Publication bias was assessed by inspection of the funnel plot and by formal testing for "funnel plot" asymmetry using Begg's test and Egger's test [24]. Sensitivity analysis was conducted to determine whether the differences in study design, sample size, age and race affected our study conclusions.

Statistical analyses were conducted with the use of the Review Manager, version 5.0 (Nordic Cochrane Centre Copenhagen, Denmark) and STATA, version 11.2 (STATA Corp, College Station, TX, USA). All $P$-values were two-tailed, and $P$-values $<0.05$ were deemed as statistically significant.

\section{Results}

Overview of included studies for the systematic review and meta-analysis

A literature search in the database of MEDLINE and EBSCO identified 350 studies, 333 of which were excluded based on the reasons listed in Fig. 1. Seventeen articles [12, 13, 19, 25-38] fulfilled the inclusion criteria and were included in this systematic review and metaanalysis, including $7[12,13,19,26,27,29,32]$ crosssectional studies, and 10 [25, 28, 30, 31, 33-38] cohort studies. Descriptive information for each included study in this systematic review and meta-analysis were shown in Table 1. Besides, the results from seventeen studies have been included in Table 2 .

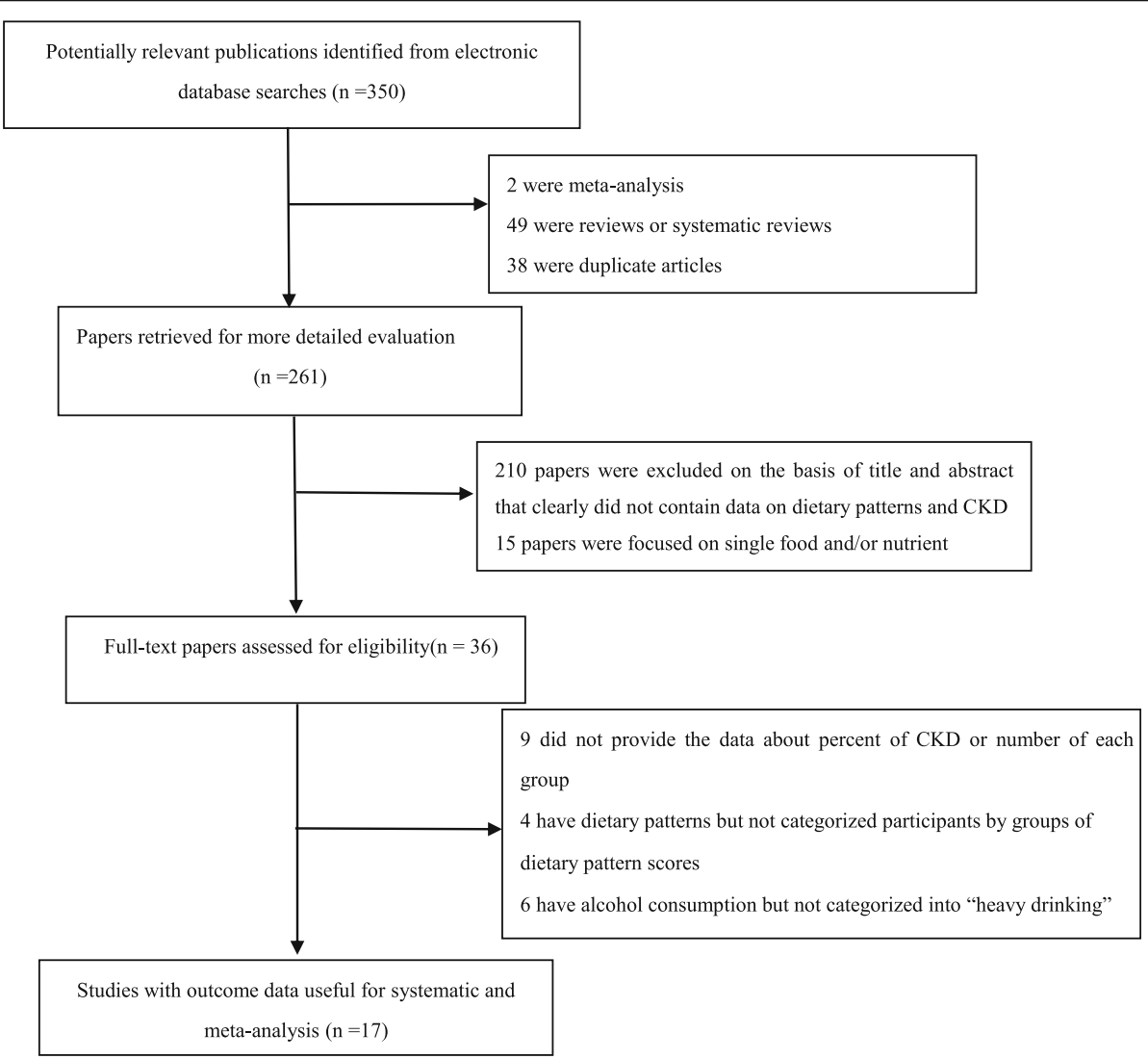

Fig. 1 Flow chart of article screening and selection process 
Table 1 Characteristics of 17 studies included in the meta-analysis (-2020)

\begin{tabular}{|c|c|c|c|c|c|c|c|}
\hline $\begin{array}{l}\text { Author } \\
\text { Publication } \\
\text { Year }\end{array}$ & Location & $\begin{array}{l}\text { Study } \\
\text { design }\end{array}$ & $\begin{array}{l}\text { Total } \\
\text { number } \\
\text { of } \\
\text { subjects }\end{array}$ & Age & $\begin{array}{l}\text { Diet- } \\
\text { assessment } \\
\text { method }\end{array}$ & Factors adjusted for in analysis & $\begin{array}{l}\text { Dietary patterns } \\
\text { identified }\end{array}$ \\
\hline $\begin{array}{l}\text { Mazidi et al. } \\
2018 \text { [12] }\end{array}$ & $\begin{array}{l}\text { United } \\
\text { states }\end{array}$ & $\begin{array}{l}\text { Cross- } \\
\text { sectional }\end{array}$ & 21,649 & $\geq 18 y$ & FFQ & $\begin{array}{l}\text { Age, sex, race, body mass index, triglyceride, } \\
\text { high density lipoprotein, diabetes,and } \\
\text { hypertension }\end{array}$ & $\begin{array}{l}\text { Saturated-MUFA; } \\
\text { minerals and } \\
\text { vitamins; Cholesterol- } \\
\text { PUFA }\end{array}$ \\
\hline $\begin{array}{l}\text { Shi et al. } \\
2018 \text { [13] }\end{array}$ & China & $\begin{array}{l}\text { Cross- } \\
\text { sectional }\end{array}$ & 8429 & $\geq 18 y$ & FFQ & $\begin{array}{l}\text { Age, gender, intake of energy,education, } \\
\text { income, urbanization level, smoking, alcohol } \\
\text { drinking, physical activity, overweight/ } \\
\text { obesity, hypertension, and diabetes. }\end{array}$ & $\begin{array}{l}\text { Traditional southern; } \\
\text { Modern. }\end{array}$ \\
\hline
\end{tabular}

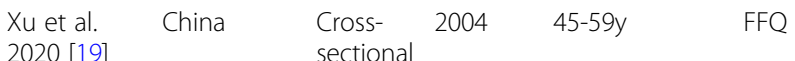

Yuzbashian Iran Cohort $5904 \geq 30 y \quad$ FFQ
et al. 2018 [25]

$\begin{array}{ll}\text { Kurniawan } & \text { China } \\ \text { et al. } 2019 & \text { (Taiwan) } \\ \text { [26] } & \\ & \end{array}$

Eimery
et al. 2020

[27]

\begin{tabular}{|c|c|c|c|c|c|}
\hline $\begin{array}{l}\text { Asghari } \\
\text { et al. } 2018 \\
\text { [28] }\end{array}$ & Iran & Cohort & 1630 & $\geq 27 y$ & FFQ \\
\hline $\begin{array}{l}\text { Paterson } \\
\text { et al. } 2018 \\
\text { [29] }\end{array}$ & $\begin{array}{l}\text { United } \\
\text { Kingdom }\end{array}$ & $\begin{array}{l}\text { Cross- } \\
\text { sectional }\end{array}$ & 1033 & $56-100 y$ & FFQ \\
\hline $\begin{array}{l}\text { Lara et al. } \\
2019 \text { [30] }\end{array}$ & $\begin{array}{l}\text { United } \\
\text { states }\end{array}$ & Cohort & 16,068 & $\geq 45 y$ & FFQ \\
\hline $\begin{array}{l}\text { Hu et al. } \\
2019 \text { [31] }\end{array}$ & $\begin{array}{l}\text { United } \\
\text { states }\end{array}$ & Cohort & 12,155 & $45-64 y$ & FFQ \\
\hline $\begin{array}{l}\text { Rouhani } \\
\text { Hossein } \\
\text { et al. } 2019 \\
{[32]}\end{array}$ & Iran & $\begin{array}{l}\text { Cross- } \\
\text { sectional }\end{array}$ & 221 & Mean:56.5y & FFQ \\
\hline $\begin{array}{l}\text { Huang } \\
\text { et al. }\end{array}$ & Sweden & Cohort & 1110 & $\begin{array}{l}\text { Approximately } \\
70 \text { y }\end{array}$ & FFQ \\
\hline
\end{tabular}

Age (continuous), gender, income (continuous), education level (<high school, high school, >high school), physical activity level (light, moderate, heavy), smoking status (never, current, former), BMI (continuous), T2DM(yes/no) and hypertension (yes/no), total energy intake (continuous)

age (continuous), sex (male, female), smoking (never, current smoker), total energy intake (continuous), body mass index (BMl; continuous), angiotensinconverting enzyme inhibitor (ACEi; yes, no) and physical activity (low, moderate and high)

age, gender, BMI, smoking status, drinking status, physical activity, high cardiovascular risk profile, hypertension status (except hypertension variable), diabetes status (except diabetes variable), albumin, and CRP

Age, sex, BMl, smoking status, physical activity, BP, use of medications, dietary intakes of protein, potassium, calcium, magnesium and phosphorous, supplement intake, socioeconomic status, and energy intake

Age, sex, smoking, total energy intake, physical activity, and body mass index, diabetes and hypertension

Traditional southern Chinese; Western;

Grains-vegetables Grans 
Table 1 Characteristics of 17 studies included in the meta-analysis (-2020) (Continued)

\begin{tabular}{|c|c|c|c|c|c|c|c|}
\hline $\begin{array}{l}\text { Author } \\
\text { Publication } \\
\text { Year }\end{array}$ & Location & $\begin{array}{l}\text { Study } \\
\text { design }\end{array}$ & $\begin{array}{l}\text { Total } \\
\text { number } \\
\text { of } \\
\text { subjects }\end{array}$ & Age & $\begin{array}{l}\text { Diet- } \\
\text { assessment } \\
\text { method }\end{array}$ & Factors adjusted for in analysis & $\begin{array}{l}\text { Dietary patterns } \\
\text { identified }\end{array}$ \\
\hline $\begin{array}{l}\text { Hu et al. } \\
2020 \text { [34] }\end{array}$ & $\begin{array}{l}\text { United } \\
\text { states }\end{array}$ & Cohort & 12,692 & $45-64 y$ & Questionnaire & $\begin{array}{l}\text { Total energy intake, age, sex, race-center, in- } \\
\text { come, education level, health insurance, } \\
\text { smoking, physical activity, diabetes status, } \\
\text { hypertension status, body mass index, base- } \\
\text { line estimated glomerular filtration rate }\end{array}$ & drinker \\
\hline $\begin{array}{l}\text { Koning } \\
\text { et al. } 2015 \\
\text { [35] }\end{array}$ & Netherlands & Cohort & 5476 & $28-75 y$ & Questionnaire & $\begin{array}{l}\text { Age, sex, height, weight, smoking status, } \\
\text { parental history of CKD, history of } \\
\text { cardiovascular disease, and educational level }\end{array}$ & Alcohol consumption \\
\hline $\begin{array}{l}\text { Sato et al. } \\
2014 \text { [36] }\end{array}$ & Japan & Cohort & 9112 & $40-55 y$ & Questionnaire & $\begin{array}{l}\text { age, body mass index, systolic blood } \\
\text { pressure, diastolic blood pressure,fasting } \\
\text { plasma glucose, smoking habits } \\
\text { (nonsmokers, past smokers, and current } \\
\text { smokers), and regular leisure-time physical } \\
\text { activity (yes/no). }\end{array}$ & Drinking pattern \\
\hline $\begin{array}{l}\text { Okada et al. } \\
2019 \text { [37] }\end{array}$ & Japan & Cohort & 9116 & $40-55 y$ & Questionnaire & $\begin{array}{l}\text { Age, BMI, systolic blood pressure, diastolic } \\
\text { blood pressure, fasting plasma glucose, } \\
\text { smoking habits (nonsmokers, past smokers, } \\
\text { and current smokers), and regular leisure- } \\
\text { time physical activity (yes/no),eGFR at } \\
\text { baseline }\end{array}$ & Drinkers \\
\hline $\begin{array}{l}\text { Foster et al. } \\
2015 \text { [38] }\end{array}$ & $\begin{array}{l}\text { United } \\
\text { kingdom }\end{array}$ & Cohort & 1964 & Mean:62.5y & FFQ & $\begin{array}{l}\text { other listed lifestyle factors, age, sex, } \\
\text { baseline eGFR, BMI, hypertension, diabetes, } \\
\text { and dipstick proteinurial }\end{array}$ & Alcohol consumption \\
\hline
\end{tabular}

BMI: body mass index;DASH: dietary approaches to stop hypertension;BP: blood pressure; FFQ: food frequency questionnaire;T2DM:type 2 diabetes mellitus

\section{Healthy dietary pattern}

The healthy dietary pattern is characterized by high intake of vegetables, fruits, fish, low-fat milk and whole grains. The association between "healthy" dietary pattern and the risk of CKD was shown in Fig. 2. There was evidence of a lower risk of CKD in the highest compared with the lowest category of "healthy" dietary pattern (OR=0.69; CI: 0.57, 0.84; $P=0.0001)$ where all studies were combined in the random-effects model. The heterogeneity was apparent in all the studies $(P<0.00001$; $\left.\mathrm{I}^{2}=83 \%\right)$.

\section{Western-type dietary pattern}

The Western-type dietary pattern is characterized by high intakes of all kinds of red and/or processed meats, refined grains, sweets, high-fat dairy products and highfat gravy. Figure 3 showed the association between western-type dietary pattern and the risk of CKD. There was evidence of a higher risk of CKD in the highest compared with the lowest category of western-type dietary pattern ( $\mathrm{OR}=1.86$; $\mathrm{CI}: 1.21,2.86 ; P=0.005)$. A randomeffects model was used to assess the data. The heterogeneity was apparent in all the studies $\left(P<0.00001 ; \mathrm{I}^{2}=97 \%\right)$.

\section{Drinking pattern}

The drinking pattern is characterized by high intakes of alcohol-containing beers, red wine, and white spirits. Four articles identified heavy drinking pattern in this meta-analysis. There was evidence of a lower risk of CKD in the highest compared with the lowest category of heavy drinking pattern $(\mathrm{OR}=0.67 ; 95 \% \mathrm{CI}$ : 0.56-0.80; $P<0.0001)$ in Fig. 4. Data from these studies were assessed using a fixed-effects model, and there was no obvious evidence of heterogeneity $\left(P=1.0 ; \mathrm{I}^{2}=0\right)$. Pooled results from five articles identified light-moderate drinking pattern. Figure 5 showed an obvious evidence of a lower risk of CKD in the light-moderate drinking compared with non-drinking $(\mathrm{OR}=0.76$; 95\% CI: 0.71-0.81; $P<0.0001)$. Data from these studies were assessed using fixed-effects model, and there was no obvious evidence of heterogeneity $\left(P=0.93 ; \mathrm{I}^{2}=0\right)$.

\section{Publication bias}

Visual inspection of the funnel plots revealed little evidence of asymmetry, and and thus little evidence of publication bias (highest compared with lowest category: healthy pattern $P=0.205$; western-type pattern $P=0.314$; heavy drinking pattern $P=0.855$; light-moderate drinking pattern $P=0.929)$.

\section{Quality assessment}

The quality of each study in terms of population and sampling methods, description of exposure and outcomes, and statistical adjustment of data, is summarized in Additional file 1: Appendix 1. All studies received a score of 6 or higher on the Newcastle-Ottawa Quality 
Table 2 The results from 17 studies included in this systematic review and meta-analysis (-2020)

\begin{tabular}{|c|c|c|}
\hline $\begin{array}{l}\text { Author/Publication } \\
\text { Year }\end{array}$ & $\begin{array}{l}\text { Countries/ } \\
\text { areas }\end{array}$ & Results \\
\hline Mazidi et al. 2018 [12] & $\begin{array}{l}\text { United } \\
\text { states }\end{array}$ & Vitamins and trace elements intake are associated with lower risk of prevalent CKD. \\
\hline Shi et al. 2018 [13] & China & $\begin{array}{l}\text { Traditional southern dietary pattern is positively associated, and modern dietary pattern is inversely } \\
\text { associated, with CKD among Chinese adults. }\end{array}$ \\
\hline Xu et al. 2020 [19] & China & $\begin{array}{l}\text { The Western pattern is associated with an increased risk, whereas the grains-vegetables pattern is associated } \\
\text { with a reduced risk for CKD. }\end{array}$ \\
\hline $\begin{array}{l}\text { Yuzbashian et al. } \\
2018[25]\end{array}$ & Iran & $\begin{array}{l}\text { Higher adherence to the low-sodium DASH-style diet might be associated with a lower risk of incident CKD } \\
\text { among high-risk adults. }\end{array}$ \\
\hline $\begin{array}{l}\text { Kurniawan et al. } \\
2019[26]\end{array}$ & $\begin{array}{l}\text { China } \\
\text { (Taiwan) }\end{array}$ & $\begin{array}{l}\text { The RRR-derived kidney function-related dietary pattern, characterized by high intake of processed and } \\
\text { animal foods and low intake of plant foods, predicts the risks for developing cardiovascular disease and } \\
\text { moderately/severely impaired kidney function among middle-aged and older adults. }\end{array}$ \\
\hline Eimery et al. 2020 [27] & Iran & $\begin{array}{l}\text { Higher adherence to the healthy dietary pattern may improve renal function while Iranian traditional } \\
\text { pattern was associated with significantly increased odds of incident CKD and albuminuria. }\end{array}$ \\
\hline Asghari et al. 2018 [28] & Iran & $\begin{array}{l}\text { The high fat, high sugar dietary pattern was associated with significantly increased (46\%) odds of incident } \\
\text { CKD, whereas a lacto-vegetarian dietary pattern may be protective against the occurrence of CKD by } 43 \% \text {. }\end{array}$ \\
\hline Paterson et al. 2018 [29] & $\begin{array}{l}\text { United } \\
\text { Kingdom }\end{array}$ & $\begin{array}{l}\text { An unhealthy dietary pattern was associated with lower renal function and greater prevalence of chronic } \\
\text { kidney disease. }\end{array}$ \\
\hline Lara et al. 2019 [30] & $\begin{array}{l}\text { United } \\
\text { states }\end{array}$ & $\begin{array}{l}\text { Adherence to a plant-based dietary pattern was inversely associated with eGFR }<60 \mathrm{ml} / \mathrm{min} / 1.73 \mathrm{~m}^{2} \text {, whereas } \\
\text { the Southern dietary pattern was positively associated with eGFR }<60 \mathrm{ml} / \mathrm{min} / 1.73 \mathrm{~m}^{2} \text {. }\end{array}$ \\
\hline Hu et al. 2019 [31] & $\begin{array}{l}\text { United } \\
\text { states }\end{array}$ & Higher adherence to healthy dietary patterns during middle age was associated with lower risk of CKD. \\
\hline $\begin{array}{l}\text { Rouhani Hossein et al. } \\
2019[32]\end{array}$ & Iran & high fat dietary pattern was directly associated with progression of CKD. \\
\hline Huang et al. 2013 [33] & Sweden & Adherence to a Mediterranean dietary pattern is associated with lower likelihood of CKD in elderly men. \\
\hline Hu et al. 2020 [34] & $\begin{array}{l}\text { United } \\
\text { states }\end{array}$ & Consuming a low or moderate amount of alcohol may lower the risk of developing CKD \\
\hline Koning et al. 2015 [35] & Netherlands & Alcohol consumption was inversely associated with the risk of developing CKD. \\
\hline Sato et al. 2014 [36] & Japan & $\begin{array}{l}\text { Among middle-aged Japanese men, the people who drank middle-range quantity, specifically who drank } \\
\text { 4-7 days/week, had lower risk of CKD than nondrinkers. }\end{array}$ \\
\hline Okada et al. 2019 [37] & Japan & $\begin{array}{l}\text { Serum uric acid level and daily alcohol consumption were independently associated with the risk of CKD. } \\
\text { Nondrinkers with the highest serum uric acid level had the highest risk of CKD }\end{array}$ \\
\hline Foster et al. 2015 [38] & $\begin{array}{l}\text { United } \\
\text { kingdom }\end{array}$ & $\begin{array}{l}\text { No associations were observed with physical activity, smoking status, or alcohol intake with incident eGFR } \\
<60 \text { or rapid eGFR decline (all } p>0.19 \text { ). }\end{array}$ \\
\hline
\end{tabular}

\begin{tabular}{|c|c|c|c|c|c|c|c|c|c|}
\hline \multirow[b]{2}{*}{ Study or Subgroup } & \multicolumn{2}{|c|}{ highest category } & \multicolumn{2}{|c|}{ lowest category } & \multirow[b]{2}{*}{ Weight } & \multirow{2}{*}{$\begin{array}{l}\text { Odds Ratio } \\
\text { M-H. Random, } 95 \% \mathrm{Cl}\end{array}$} & \multirow{2}{*}{\multicolumn{3}{|c|}{$\begin{array}{l}\text { Odds Ratio } \\
\text { M-H, Random, } 95 \% \mathrm{Cl}\end{array}$}} \\
\hline & Events & Total & Events & Total & & & & & \\
\hline Asghari 2018 & 52 & 543 & 91 & 543 & $8.7 \%$ & $0.53[0.37,0.76]$ & $\mp$ & & \\
\hline Eimery 2020 & 22 & 89 & 20 & 88 & $4.7 \%$ & $1.12[0.56,2.23]$ & & & \\
\hline Hu 2019 & 760 & 2431 & 810 & 2431 & $12.3 \%$ & $0.91[0.81,1.03]$ & $=$ & & \\
\hline Huang 2013 & 56 & 147 & 131 & 247 & $7.9 \%$ & $0.54[0.36,0.83]$ & - & & \\
\hline Lara 2019 & 228 & 3895 & 254 & 3889 & $11.5 \%$ & $0.89[0.74,1.07]$ & of & & \\
\hline Mazidi 2018 & 320 & 5910 & 495 & 4979 & $12.1 \%$ & $0.52[0.45,0.60]$ & $=$ & & \\
\hline Paterson 2018 & 138 & 206 & 159 & 206 & $7.6 \%$ & $0.60[0.39,0.93]$ & $\rightarrow$ & & \\
\hline Rouhani Hossein 2019 & 24 & 55 & 17 & 55 & $4.0 \%$ & $1.73[0.79,3.78]$ & & & \\
\hline Shi 2016 & 147 & 2101 & 190 & 2108 & $11.0 \%$ & $0.76[0.61,0.95]$ & - & & \\
\hline Xu 2020 & 53 & 501 & 89 & 501 & $8.7 \%$ & $0.55[0.38,0.79]$ & - & & \\
\hline Yuzbshian 2018 & 190 & 1569 & 289 & 1471 & $11.3 \%$ & $0.56[0.46,0.69]$ & $\tau$ & & \\
\hline Total $(95 \% \mathrm{Cl})$ & & 17447 & & 16518 & $100.0 \%$ & $0.69[0.57,0.84]$ & 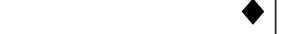 & & \\
\hline Total events & 1990 & & 2545 & & & & & & \\
\hline \multicolumn{6}{|c|}{$\begin{array}{l}\text { Heterogeneity: } \mathrm{Tau}^{2}=0.07 ; \mathrm{Chi}^{2}=58.76, \mathrm{df}=10(P<0.00001) ; I^{2}=83 \% \\
\text { Test for overall effect: } Z=3.84(P=0.0001)\end{array}$} & & $\begin{array}{lll}0.01 & 0.1 & 1\end{array}$ & $\begin{array}{c}10 \\
\text { Favours control }\end{array}$ & 100 \\
\hline
\end{tabular}




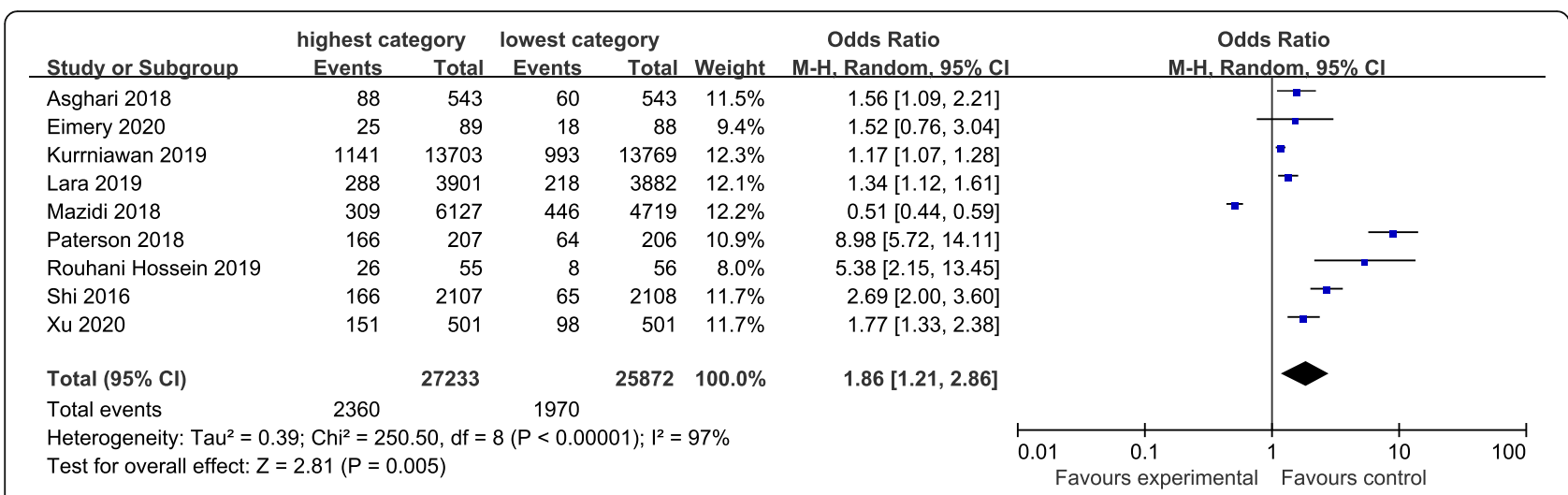

Fig. 3 Forest plot for ORs of the highest compared with the lowest category of intake of the Western-type dietary pattern and CKD

assessment scale and were considered to be of high methodological quality [12, 13, 19, 25, 26, 28, 30-38].

\section{Sensitivity analysis}

To further identify the relationship between dietary patterns and CKD risk, we performed a sensitivity analysis. It showed that differences in age, sample size, race and study design had an important effect on the association between dietary patterns and CKD risk. When the highest category was compared with the lowest category of western-type dietary pattern, the western-type dietary pattern/CKD association was stronger in a small sample size, and subjects were more than 50 years old, and yellow and other. In addition, the inverse association was obvious for those in the highest compared with the lowest category of heavy drinking pattern in studies having a large sample size. Owing to these factors having a strong effect on the association between dietary patterns and CKD risk, their differences may partially explain the heterogeneity between studies (Table 3 ).

\section{Discussion}

Limited literature has investigated the link between dietary patterns and the risk of CKD in Chinese population $[13,19]$, and has yielded inconclusive results. To the best of our knowledge, the present study is the latest systematic review and meta-analysis on the association of dietary patterns with the risk of CKD. In the current study, the results showed that a healthy dietary pattern and alcohol drinking were associated with lower risk of CKD, whereas a Western-type dietary pattern was associated with higher risk of CKD. Data from 17 studies involving 149,958 participants were included in the present analysis.

In our analyses, a healthy dietary pattern was associated with lower risk of CKD. Our findings are in agreement with previous a study by Bach et al., reporting that a healthy dietary pattern was associated with a lower incidence of CKD [39]. however, almost all of included studies from previous meta-analysis were conducted in the United States or Iran. Thus, the results may not be extrapolated to other populations around the world. Besides, the previous meta-analysis was based only on cohort studies without other types of studies, e.g. randomized trails, and the results may have selection bias. Anywhere, there are several plausible explanations for the protective effect of healthy pattern on CKD. First, the healthy pattern tends to have high loadings of whole grains, fruit and vegetables, containing large amounts of dietary fiber. Some previous studies reported that high intake of dietary fiber was significantly associated with a decreased risk of CKD [40]. Although the exact mechanism remains unclear, dietary fiber may reduce the levels of inflammatory markers, e.g.interleukin 6(IL6), total

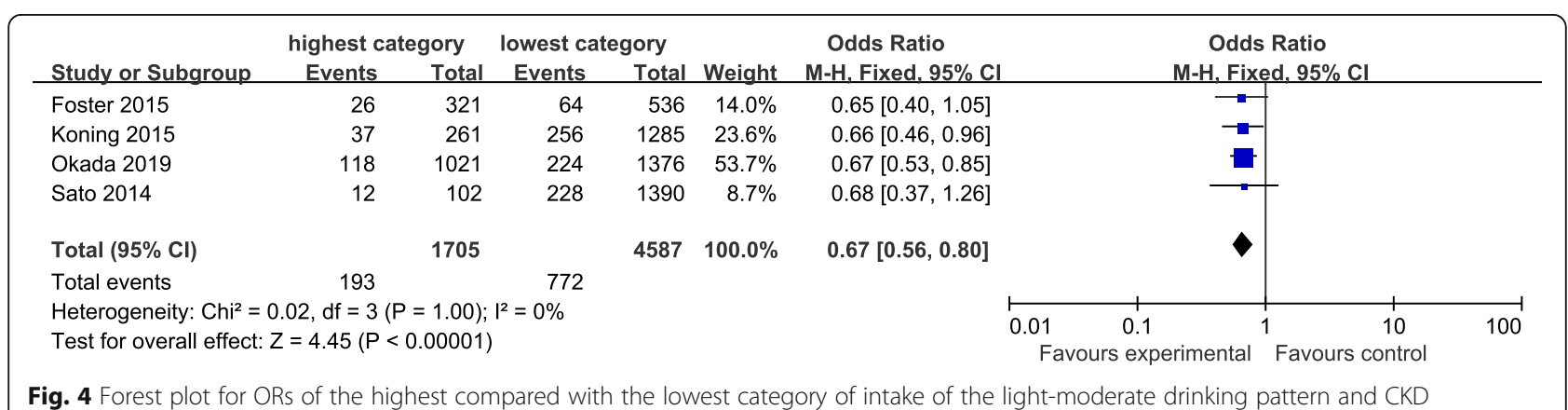




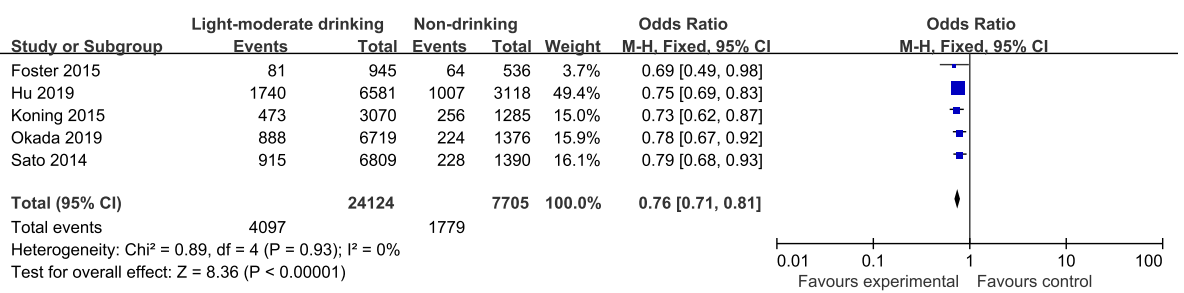

Fig. 5 Forest plot for ORs of the highest compared with the lowest category of intake of the heavy-drinking pattern and CKD

homocysteine and C-reactive protein (CRP), which are common precursors to CKD [41]. Second, the protective effects of fruits and vegetables consumption against CKD may be related to their high concentration of folate. In a cross-sectional study conducted in Australia, folate intake (base on estimated average recommended) was associated with a $40-45 \%$ decreased risk of CKD [42]. Finally, vegetables and fruits are rich in antioxidants, for example vitamin $\mathrm{C}$, vitamin $\mathrm{E}$, and other carotenoids compounds. It has been widely agreed that antioxidants play an important role in reducing the risk of CKD [43].

The Western-type dietary pattern was significantly associated with higher risk of CKD. Our results were consistent with previous findings [19], showing that western pattern was related to an elevated risk of CKD. $\mathrm{Xu}$ et al. [19] studied the Western dietary pattern defined byred meats, poultry and organs, processed and cooked meat, eggs, seafood, cheese, fast foods, snacks, chocolates, alcoholic beverages, coffee that was positively associated with the risk of CKD. Due to the cross-sectional design of this study, $\mathrm{Xu}$ et al. cannot infer causality. Meanwhile, the participants were predominately recruited Hangzhou city, China and not a random sample of the general population. The findings cannot be generalizable to other populations. As we all know, the Western pattern is usually composed of red and/or processed meat, refined grains, sweets, high-fat dairy products, butter, potatoes and high-fat gravy. Thus, several plausible explanations have been proposed to elucidate the detrimental association of Western-type pattern with CKD risk. First, high intake of meat containing large amounts of saturated fat and cholesterol, was strongly associated with the development of CKD [43]. Second, processed meat and fast foods often contain high content of salt. Previous a study reported that high salt consumption is positively associated with the development of CKD [5]. Third, some previous studies have shown that western dietary pattern was associated with higher risk of obesity, hypertension and T2DM, all of these factors have been documented to be important risk factors for CKD [40]. Finally, soft drinks contain large amounts of fructose. Previous studies have shown that sugar consumption, especially in the form of fructose, was associated with an increased risk of kidney disease [44].

Light-moderate and heavy drinking patterns were associated with lower risk of CKD in the present metaanalysis. A previous systematic review and meta-analysis of alcohol consumption and the risk of renal damage demonstrated that high alcohol consumption was associated with a $17 \%$ decreased risk of CKD [45]. Besides, a 10-year longitudinal Japanese study including 123,764 adults with eGFR $\geq 60 \mathrm{ml} / \mathrm{min} / 1.73 \mathrm{~m}^{2}$ showed that $\mathrm{mod}$ erate alcohol consumption $(<20 \mathrm{~g} / \mathrm{d})$ was associated with a decreased risk of CKD [46]. Conversely, a prior study found no significant relationship between heavy drinking pattern and CKD in a middle-aged Japanese men [36]. Thus, the relationship between alcohol consumption and the risk of CKD remains controversial. In fact, alcohol

Table 3 Dietary patterns and CKD: sensitivity analysis

\begin{tabular}{|c|c|c|c|c|c|}
\hline Study characteristic & Category & $\begin{array}{l}\text { Healthy dietary } \\
\text { pattern }(95 \% \mathrm{Cl})\end{array}$ & $\begin{array}{l}\text { Western-type dietary } \\
\text { pattern }(95 \% \mathrm{Cl})\end{array}$ & $\begin{array}{l}\text { Heavy drinking } \\
\text { pattern }(95 \% \mathrm{Cl})\end{array}$ & $\begin{array}{l}\text { Light-moderate drinking } \\
\text { pattern }(95 \% \mathrm{Cl})\end{array}$ \\
\hline \multirow[t]{2}{*}{ Age } & $>50$ & $0.78(0.64,0.97)$ & $2.25(1.42,3.57)$ & $0.66(0.49,0.88)$ & $0.75(0.69,0.81)$ \\
\hline & $<50$ & $0.58(0.49,0.70)$ & $1.28(0.42,3.94)$ & $0.67(0.54,0.84)$ & $0.79(0.70,0.88)$ \\
\hline \multirow[t]{2}{*}{ Sample size } & Large (> 5000) & $0.71(0.55,0.91)$ & $1.20(0.70,2.05)$ & $0.67(0.55,0.81)$ & $0.76(0.71,0.81)$ \\
\hline & Small $(<5000)$ & $0.67(0.50,0.88)$ & $2.83(1.39,5.76)$ & $0.65(0.40,1.05)$ & $0.69(0.49,0.98)$ \\
\hline \multirow[t]{2}{*}{ Race } & White & $0.69(0.51,0.92)$ & $1.79(0.56,5.74)$ & $0.66(0.49,0.88)$ & $0.75(0.69,0.81)$ \\
\hline & Yellow and Other & $0.69(0.54,0.88)$ & $1.87(1.28,2.72)$ & $0.67(0.54,0.84)$ & $0.79(0.70,0.88)$ \\
\hline \multirow[t]{2}{*}{ Study design } & Cross-sectional & $0.70(0.53,0.91)$ & $2.04(1.15,3.64)$ & 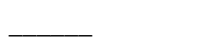 & 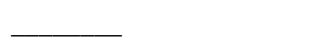 \\
\hline & Cohort & $0.69(0.54,0.88)$ & $1.38(1.18,1.63)$ & $0.67(0.56,0.80)$ & $0.76(0.71,0.81)$ \\
\hline
\end{tabular}


consumption has been recognized as one of the major risk factors for poor health outcomes. In the current study, we observed an inverse association between lightmoderate drinking pattern and the risk of CKD. There are several plausible explanations for this inverse association. First, an earlier study has demonstrated that moderate alcohol consumption can increase high-density lipoprotein (HDL) and plasma concentration of endogenous tissue-type plasminogen activator [47], thereby protecting against atherosclerosis, a major risk factor for CKD [46]. Second, polyphenols rich in red wine were widely believed to have beneficial health effects due to their anti-oxidant properties [39]. Studies have shown that long-term exposure to polyphenols may reduce kidney injury by induction of superoxidase dismutase, glutathione peroxidase, and catalase [48]. Third, moderate alcohol consumption has been found to be associated with decreased risk of coronary heart disease, which shares similar risk factor and pathophysiology with CKD [34, 49]. Meanwhile, we also observed an inverse relationship between heavy drinking pattern and the risk of CKD in this analysis. However, high alcohol consumption of more than two drinks per day was shown to increase the risk of ESRD in the American population [50]. As far as we know, excessive alcohol consumption could interfere with electrolyte and acid-base balance and body fluids, which can negatively affect kidney function [51]. Besides, previous studies have also shown that heavy alcohol consumption is positively associated with hypertension, one of the major risk factors for CKD [52]. Furthermore, excessive alcohol consumption have become a worldwide problem, with approximately 140 million people having alcoholism [53]. In short, heavy or excessive drinking should be discouraged.

In this meta-analysis, there was significant heterogeneity across the part of included studies, which may be attributed to differences in the ways that healthy and western-type dietary patterns were defined or dissimilar characteristics of individuals sticking to healthy/unhealthy in the East and West countries. Although we have tried to match the similar factor loadings as much as possible between included studies, the actual factor loading of the same foods within the similar dietary pattern was never exactly the same between studies [54]. There may also be other variables that cannot be explained, e.g. cooking methods. These variables may be culturally related and vary by race. In the sensitivity analysis, we also observed that differences in race had an important effect on the association between dietary patterns and CKD risk. Nevertheless, because of the relatively small number of included studies, we cannot to explore all potential sources of heterogeneity. Future studies could shed light on whether other variables, such as cooking methods, may influence the association between dietary patterns and CKD risk.

\section{Strengths and limitations}

This systematic review and meta-analysis had several strengths. First, CKD diagnosis was confirmed by glomerular filtration rate (eGFR,in $\mathrm{ml} / \mathrm{min} / 1.73 \mathrm{~m}^{2}$ ), and those with $\mathrm{eGFR}<60 \mathrm{ml} / \mathrm{min} / 1.73 \mathrm{~m}^{2}$ or the presence of albuminuria were classified as having CKD, avoiding misdiagnosis bias. Second, this is the latest systematic review and meta-analysis on the association of dietary patterns with the risk of CKD. We not only have an update on the previous meta-analysis (Bach et al., 2019, ${ }^{39]}$, but also further explore the association between drinking pattern and the risk of CKD. Besides, our findings also provide a clear evidence for the association between dietary patterns and CKD risk. Third, no signs of publication bias were evident in the funnel plot, and the statistical test for publication bias was non-significant. Nonetheless, the present meta-analysis also had some limitations that should be acknowledged. First, the principal limitation was the use of potentially biased evidence. There were some inconsistencies in the confounding factors adjusted among the included studies. As a consequence, the data included in our analyses may suffer from differing degrees of completeness and accuracy. Second, 7 of 17 studies were cross-sectional in term of study design, which are more prone to recall and selection bias, especially dietary recall bias, than a cohort design. Finally, the geographical regions covered in the present meta-analysis included Asia (China, Iran and Japan), Europe (England, Sweden and Netherlands), and United States. Thus, the results of this meta-analysis could not be expanded to all populations.

\section{Conclusion}

In conclusion, this systematic review and meta-analysis indicated that a healthy dietary pattern and alcohol drinking were associated with lower risk of CKD, whereas a Western-type dietary pattern was associated with higher risk of CKD. These findings provide evidence of the role of dietary pattern in the development of $\mathrm{CKD}$, and highlight the importance of higher vegetable, fruit and whole grains and lower red meat and high-fat diet in order to be associated with lower risk of CKD. Therefore, it makes sense to provide a scientific rationable for formulating dietary guidelines.

\section{Supplementary Information}

The online version contains supplementary material available at https:/doi. org/10.1186/s12937-020-00661-6.

\section{Additional file 1}

Abbreviations

CKD: Chronic kidney disease; OR: Odds ratio; Cl: Confidence interval; BMI: Body mass index; WC: Waist circumference; WHR: Waist-hip ratio; SBP: Systolic blood pressure; DBP: Diastolic blood pressure; HR: Hazard ratios; 
RR: Relative risks; FFQ: Food frequency questionnaire; HDL: High- density lipoprotein

\section{Acknowledgements}

We thank all participants from the Department of Geriatric, Department of Endocrinology/ Rheumatology and Nephrology, The Third Affiliated Hospital of Zhejiang Chinese Medical University and Department of Nutrition, Zhejiang Hospital for their assistance and support. Besides, we also acknowledge Mrs. Huang and Zhang for their important contributions to data collection and analysis in this study.

\section{Authors' contributions}

The authors' responsibilities were as follows: L.-Q. H. and L. S. took responsibility for data integrity and the accuracy of data analysis. L.S. was responsible for study concept and design. Y.-Q.H. and X.-Y.Z. acquired the data. X.-H.W. and L.-Q.H were responsible for analysis and interpretation of the data. L.S. and Y.-Q.H. performed the statistical analysis. L.-Q. H. and L. S. drafted the manuscript. All authors critically revised the manuscript for important intellectual content. The author(s) read and approved the final manuscript.

\section{Funding}

This study was supported by Natural Science Foundation of Zhejiang (No. LY17H030008), the joint construction of projects by provinces and the ministry of education (No. 2014PYA002), Traditional Chinese Medicine Research Project of Zhejiang (No.2020ZB009), and Medical and Health research fund project of Zhejiang Province (No. 2017KY190).

\section{Availability of data and materials}

All the data in this meta-analysis are from published studies and we take responsibilities for the data integration process and the accuracy of the statistical analyses process.

\section{Ethics approval and consent to participate}

Ethics approval and consent to participate is not required for this study.

\section{Consent for publication}

Not Applicable.

\section{Competing interests}

The authors declare no conflict of interest associated with this paper.

\section{Author details}

'Department of Geriatric, The Third Affiliated Hospital of Zhejiang Chinese Medical University, No 219 Moganshan road, Hangzhou 31005 Zhejiang, People's Republic of China. ${ }^{2}$ Department of Endocrinology/Rheumatology and Nephrology, The Third Affiliated Hospital of Zhejiang Chinese Medical University, No 219 Moganshan road, Hangzhou 31005 Zhejiang, People's Republic of China. ${ }^{3}$ Department of Digestion, Zhejiang Hospital, No 12 Linyin Road, Xihu district, Hangzhou 310013 Zhejiang, People's Republic of China. ${ }^{4}$ Department of Nutrition, Zhejiang Hospital, Xihu district, Hangzhou 310013 Zhejiang, People's Republic of China.

Received: 26 June 2020 Accepted: 22 December 2020

Published online: 08 January 2021

\section{References}

1. Hill NR, Fatoba ST, Oke JL, et al. Global prevalence of chronic kidney disease-a systematic review and meta-analysis. PLoS One. 2016;11:e0158765.

2. Coresh J, Selvin E, Stevens LA, et al. Prevalence of chronic kidney disease in the United States. JAMA. 2007;298:2038-47.

3. Barreto SM, Ladeira RM, Duncan BB, et al. Chronic kidney disease among adult participants of the ELSA-Brasil cohort: association with race and socioeconomic position. J Epidemiol Community Health. 2016;70:380-9.

4. Zhang $L$, Wang $F$, Wang $L$, et al. Prevalence of chronic kidney disease in China: a cross-sectional survey. Lancet. 2012;379:815e22.

5. Jha V, Garcia-Garcia G, Iseki K, et al. Chronic kidney disease: global dimension and perspectives. Lancet. 2013;382:260-72.

6. Hu EA, Rebholz CM. Can dietary patterns modify risk for CKD?Clin. J Am Soc Nephrol. 2019;14:1419-20.
7. Ash S, Campbell KL, Bogard J, et al. Nutrition prescription to achieve positive outcomes in chronic kidney disease: a systematic review. Nutrients. 2014;6:416-51.

8. Cheung $\mathrm{CL}$, Sahni $\mathrm{S}$, Cheung BM, et al. Vitamin $\mathrm{K}$ intake and mortality in people with chronic kidney disease from NHANES III. Clin Nutr. 2015; 34:235-40.

9. Jankowska M, Szupryczyńska N, Dębska-Ślizień A, et al. Dietary intake of vitamins in different options of treatment in chronic kidney disease: is there a deficiency? Transplant Proc. 2016;48:1427-30.

10. Li Y, LV MR, Wei YJ, et al. Dietary patterns and depression risk: a metaanalysis. Psychiatry Res. 2017;253:373-82.

11. Hu FB. Dietary pattern analysis: a new direction in nutritional epidemiology. Curr Opin Lipidol. 2002;13:3-9.

12. Mazidi M, Gao HK, Kengne AP. Food patterns are associated with likelihood of CKD in US adults. Sci Rep. 2018:8:10696.

13. Shi Z, Taylor AW, Riley M, et al. Association between dietary patterns, cadmium intake and chronic kidney disease among adults. Clin Nutr. 2018; 37:276-84.

14. Lee $H S$, Lee $K B$, Hyun $Y Y$, et al. DASH dietary pattern and chronic kidney disease in elderly Korean adults. Eur J Clin Nutr. 2017;71:755-61.

15. Wai SN, Kelly JT, Johnson DW, Campbell KL. Dietary patterns and clinical outcomes in chronic kidney disease: the CKD.QLD nutrition study. J Ren Nutr. 2017:27:175-82.

16. Lin J, Fung TT, Hu FB, Curhan GC. Association of dietary patterns with albuminuria and kidney function decline in older white women: a subgroup analysis from the Nurses' health study. Am J Kidney Dis. 2011;57:245-54.

17. Gutiérrez OM, Muntner P, Rizk DV, et al. Dietary patterns and risk of death and progression to ESRD in individuals with CKD: a cohort study. Am J Kidney Dis. 2014;64:204-13.

18. Heindel J, Baid-Agrawal S, Rebholz CM, et al. Association between dietary patterns and kidney function in patients with chronic kidney disease: a cross-sectional analysis of the German chronic kidney disease study. J Ren Nutr 2019; pii: S1051-2276(19)30347-4.

19. Xu SS, Hua J, Huang YQ, Shu L. Association between dietary patterns and chronic kidney disease in a middle-aged Chinese population. Public Health Nutr. 2020:23:1058-66.

20. Lu PY, Shu L, Shen SS, et al. Dietary patterns and pancreatic cancer risk: a meta-analysis. Nutrients 2017;9: pii: E38.

21. Higgins JP, Thompson SG, Deeks JJ, Altman DG. Measuring inconsistency in meta-analyses. BMJ. 2003:327:557-60.

22. Stang A. Critical evaluation of the Newcastle-Ottawa scale for the assessment of the quality of nonrandomized studies in meta-analyses. Eur J Epidemiology. 2010;25:603-5

23. Feng $Y L$, Shu $L$, Zheng PF, et al. Dietary patterns and colorectal cancer risk: a meta-analysis. Eur J Cancer Prev. 2017;26:201-11.

24. Begg CB, Mazumdar M. (1994) operating characteristics of a rank correlation test for publication bias. Biometrics. 1994;50:1088-101.

25. Yuzbashian E, Asghari G, Mirmiran P, et al. Adherence to low-sodium dietary approaches to stop hypertension-style diet may decrease the risk of incident chronic kidney disease among high-risk patients: a secondary prevention in prospective cohort study. Nephrol Dial Transplant. 2018;33:1159-68.

26. Kurniawan $\mathrm{AL}, \mathrm{Hsu} \mathrm{CY}$, Rau HH, et al. Association of kidney function-related dietary pattern, weight status, and cardiovascular risk factors with severity of impaired kidney function in middle-aged and older adults with chronic kidney disease: a cross-sectional population study. Nutr J. 2019:18:27.

27. Eimery S, Tangestani H, Mansouri S, et al. Association between dietary patterns with kidney function and serum highly sensitive C-reactive protein in Tehranian elderly: an observational study. J Res Med Sci. 2020;25:19.

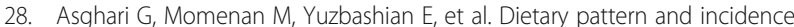
of chronic kidney disease among adults: a population-based study. Nutr Metab (Lond)2018;15:88

29. Paterson EN,Neville CE,Silvestri G,et al. Dietary patterns and chronic kidney disease: a cross-sectional association in the Irish Nun eye study. Sci Rep2018; 8:6654

30. Lara KM, Levitan EB, Gutierrez OM, et al. Dietary patterns and incident heart failure in U.S. adults without known coronary disease. J Am Coll Cardiol. 2019:73:2036-45.

31. Hu EA, Steffen LM, Grams ME, et al. Dietary patterns and risk of incident chronic kidney disease: the atherosclerosis risk in communities study. Am J Clin Nutr. 2019:110:713-21. 
32. Hossein Rouhani M, Mortazavi Najafabadi M, Esmaillzadeh A, et al. Direct association between high fat dietary pattern and risk of being in the higher stages of chronic kidney disease. Int J Vitam Nutr Res. 2019;89:261-70.

33. Huang $X$, Jiménez-Moleón JJ, Lindholm B, et al. Mediterranean diet, kidney function, and mortality in men with CKD. Clin J Am Soc Nephrol. 2013;8: $1548-55$.

34. Hu EA, Lazo M, Rosenberg SD, et al. Alcohol consumption and incident kidney disease: results from the atherosclerosis risk in communities study. J Ren Nutr. 2020:30:22-30.

35. Koning SH, Gansevoort RT, Mukamal K, et al. Alcohol consumption is inversely associated with the risk of developing chronic kidney disease. Kidney Int. 2015;87:1009-16.

36. Sato KK, Hayashi T, Uehara S, et al. Drinking pattern and risk of chronic kidney disease: the kansai healthcare study. Am J Nephrol. 2014;40:516-22.

37. Okada Y, Uehara S, Shibata M, et al. Habitual alcohol intake modifies relationship of uric acid to incident chronic kidney disease. Am J Nephrol. 2019;50:55-62.

38. Foster MC, Hwang SJ, Massaro JM, et al. Lifestyle factors and indices of kidney function in the Framingham heart study. Am J Nephrol. 2015;41: 267-74.

39. Bach K, Kelly J, Palmer S, et al. Healthy dietary patterns and incidence of chronic kidney disease: a meta-analysis of cohort studies. Clin J Am Soc Nephrol. 2019;14:1441-9.

40. Farhadnejad H, Asghari G, Mirmiran P, et al. Micronutrient intakes and incidence of chronic kidney disease in adults: Tehran lipid and glucose study. Nutrients. 2016;8:217.

41. Fried L, SolomonC SM, et al. Inflammatory and prothrombotic markers and the progression of renal disease in elderly individuals. J Am Soc Nephrol. 2004;15:3184-91.

42. Strippoli GF, Craig JC, Rochtchina E, et al. Fluid and nutrient intake and risk of chronic kidney disease. Nephrology (Carlton). 2011;16:326-34.

43. Lin J, Hu FB, Curhan GC. Associations of diet with albuminuria and kidney function decline. Clin J Am Soc Nephrol. 2010:5:836-43.

44. Karalius VP, Shoham DA. Dietary sugar and artificial sweetener intake and chronic kidney disease: a review. Adv Chronic Kidney Dis. 2013;20:157-64.

45. Cheungpasitporn W, Thongprayoon C, Kittanamongkolchai W, et al. High alcohol consumption and the risk of renal damage: a systematic review and meta-analysis. QJM. 2015;108:539-48.

46. Yamagata K, Ishida K, Sairenchi T, et al. Risk factors for chronic kidney disease in a community-based population: a 10-year follow-up study. Kidney Int. 2007;71:159-66.

47. Ridker PM, Vaughan DE, Stampfer MJ, et al. Association of moderate alcohol consumption and plasma concentration of endogenous tissue-type plasminogen activator. JAMA. 1994;272:929-33.

48. Hsu YH, Pai HC, Chang YM, et al. Alcohol consumption is inversely associated with stage 3 chronic kidney disease in middle-aged Taiwanese men. BMC Nephro. 2013;14:254.

49. Zhang XY, Shu L, Si CJ, et al. Dietary Patterns, Alcohol Consumption and Risk of Coronary Heart Disease in Adults: A Meta-Analysis.Nutrients 2015; 7: 6582-6605.

50. Perneger TV, Whelton PK, Puddey IB, Klag MJ. Risk of endstage renal disease associated with alcohol consumption. Am J Epidemiol. 1999;150:1275-81.

51. Epstein M. Alcohol's impact on kidney function. Alcohol Health Res World. 1997;21:84-92

52. Fuchs FD, Chambless LE, Whelton PK, et al. Alcohol consumption and the incidence of hypertension: the atherosclerosis risk in communities study. Hypertension. 2001;37:1242-50

53. Kepka A, Chojnowska S, Snitko R, et al. Renal carnitine excretion following abstinence after chronic drinking. Adv Med Sci. 2016;61:160-3.

54. Brennan SF, Cantwell MM, Cardwell CR, Velentzis LS, Woodside JV. Dietary patterns and breast cancer risk: a systematic review and meta-analysis. Am J Clin Nutr. 2010;91(5):1294-302.

\section{Publisher's Note}

Springer Nature remains neutral with regard to jurisdictional claims in published maps and institutional affiliations.

Ready to submit your research? Choose BMC and benefit from:

- fast, convenient online submission

- thorough peer review by experienced researchers in your field

- rapid publication on acceptance

- support for research data, including large and complex data types

- gold Open Access which fosters wider collaboration and increased citations

- maximum visibility for your research: over $100 \mathrm{M}$ website views per year

At BMC, research is always in progress.

Learn more biomedcentral.com/submissions 